\title{
Spark Plasma Sintering of Boron Carbide Ceramics Using Different Sample Geometries and Dimensions
}

\author{
M. Cengiz, B. Yavas, Y. Celik, G. Goller, O. Yucel and F.C. Sahin \\ Istanbul Technical University, Metallurgical and Materials Engineering Department \\ 34469 Maslak, Istanbul, Turkey
}

\begin{abstract}
$\mathrm{B}_{4} \mathrm{C}$ ceramics were fabricated by spark plasma sintering technique at $1700{ }^{\circ} \mathrm{C}-1800{ }^{\circ} \mathrm{C}$ for 5 min under applied pressure of $50 \mathrm{MPa}$ under vacuum atmosphere. Two different grades of $\mathrm{B}_{4} \mathrm{C}$ powder from H.C. Starck Company namely HP grade and HS grade were used in all related experiments. Effect of sample geometry and dimensions as well as sample thickness on sintering parameters were analyzed. Samples having $5 \mathrm{~mm}$ thickness and $50 \mathrm{~mm}$ diameter, $8 \mathrm{~mm}$ thickness in circular geometries and $50 \times 50$ square cross-section, $8 \mathrm{~mm}$ thickness were fabricated. Using the powder, which provided the densest sample, yttrium oxide $\left(\mathrm{Y}_{2} \mathrm{O}_{3}\right)$ was added, mixed and sintered. Optimization of SPS method production parameters for pure $\mathrm{B}_{4} \mathrm{C}$ samples and $\mathrm{B}_{4} \mathrm{C}$ samples with 5 wt\% yttrium oxide additive were accomplished. The effect of geometry on density, Vickers hardness, fracture toughness, and microstructure were examined. The hardness and fracture toughness values of the samples were evaluated by the Vickers indentation technique.
\end{abstract}

DOI: 10.12693/APhysPolA.125.260

PACS: 81.20.Ev, 81.05.Je

\section{Introduction}

Ceramic materials are attractive materials for ballistic protection applications due to their high hardness, high flexural strength, and low density when compared to metals. Among those materials, boron carbide $\left(\mathrm{B}_{4} \mathrm{C}\right)$ is evaluated as an ideal material for ballistic protection applications, especially for light armor, since it is the third hardest material after diamond and cubic boron nitride and it exhibits higher hardness and lower density when compared to other ceramics [1,2].

In recent years, spark plasma sintering (SPS) technique has been used widely for manufacturing boron carbide and related boron carbide ceramics because of the positive effects on microstructure since it prevents grain coarsening [2]. With applying external electric field, SPS enhances densification and the sintering process is completed at lower temperatures in short times without grain growth compared to the traditional methods (pressureless sintering, hot pressing, and hot isostatic pressing). These unique properties make SPS a preferable candidate for producing boron carbide ceramics $[3,4]$.

In this study $\mathrm{B}_{4} \mathrm{C}$ ceramics are produced by using SPS method and physical and mechanical characterization of those ceramics are performed. Optimization of SPS method production parameters for $\mathrm{B}_{4} \mathrm{C}$ ceramics having geometries $(50 \mathrm{~mm}$ diameter, $5 \mathrm{~mm}$ thickness, $50 \mathrm{~mm}$ diameter, $8 \mathrm{~mm}$ thickness circular; $50 \times 50 \times 8 \mathrm{~mm}^{3}$ square cross-section) and 5 wt $\% \mathrm{Y}_{2} \mathrm{O}_{3}$ added $\mathrm{B}_{4} \mathrm{C}$ will be performed. Sintering additives are expected to affect the sintering behavior, sintering conditions and enable production of secondary phases leading to mechanical changes in the sintered compacts [5].

\section{Experimental}

Commercial HS and HP grade $\mathrm{B}_{4} \mathrm{C}$ powders from German H.C. Starck Company, with an average particle size of $1.78 \mu \mathrm{m}$ and $2.95 \mu \mathrm{m}$, respectively and from the same company yttrium oxide (C quality, average particle size $0.9 \mu \mathrm{m}$ ) were used in the present study. In most of the experiments pure $\mathrm{B}_{4} \mathrm{C}$ was used. In the experiment that yttrium oxide was used as additive, suspensions were prepared by mixing $\mathrm{B}_{4} \mathrm{C}$ and $\mathrm{Y}_{2} \mathrm{O}_{3}$ powder with alumina balls in Merck quality ethanol medium by ball milling for $24 \mathrm{~h}$. The slurry was then dried and screened from $150 \mu \mathrm{m}$ openings. After screening, the dry powder was loaded in a graphite die for conducting in SPS.

The samples were sintered by using the SPS apparatus (SPS-7.40MK-VII, SPS Syntex Inc.). After applying a pressure of $50 \mathrm{MPa}$, two different heating regimes were used for sintering: one is $100^{\circ} \mathrm{C} / \mathrm{min}$ and the other is $75^{\circ} \mathrm{C} / \mathrm{min}$ from room temperature to sintering temperature. The temperature of the die was measured by an optical pyrometer. All of the samples were subjected to 5 min soaking time. Whole process was carried out in vacuum atmosphere and shrinkage, displacement, heating current, and voltage for every $5 \mathrm{~s}$ was recorded. At the end of the process, sintered compacts were obtained.

After the sintering process, the Archimedes method was used to determine the final relative densities of the compacts. Specimens, polished with a diamond paste having particle size of $1 \mu \mathrm{m}$ were subjected to the hardness and fracture toughness tests at room temperature and were evaluated by the Vickers indentation technique at a load of $1 \mathrm{~kg}$. The micrographs of all sample surfaces were observed by scanning electron microscopy (SEM; model JSM 7000F, JEOL, Tokyo, Japan).

\section{Results and discussion}

Starting powders, sample dimensions, and SPS conditions along with the relative density values of the sintered ceramics are given in Table I. The first two samples have $50 \mathrm{~mm}$ diameter and $5 \mathrm{~mm}$ thickness. $50 \mathrm{MPa}$ pressure 
is applied under vacuum atmosphere and the powders are heated with $100^{\circ} \mathrm{C} /$ min heating rate and sintered for 5 min. The sintering temperatures are defined by checking the completion of the shrinkage amounts. Maximum relative density values are achieved at the temperatures where the shrinkage is completed and the samples are kept constant at that temperature for $5 \mathrm{~min}$. Shrinkage of the HP and HS graded cylindrical samples having $50 \mathrm{~mm}$ diameter and $5 \mathrm{~mm}$ thickness are completed at $1800{ }^{\circ} \mathrm{C}$ and $1770{ }^{\circ} \mathrm{C}$, respectively. This sintering temperature difference resulted from the average grain size difference where HS is $1.78 \mu \mathrm{m}$ and HP is $2.97 \mu \mathrm{m}$. HS grade $\mathrm{B}_{4} \mathrm{C}$ have $99.4 \%$ relative density whereas $\mathrm{HP}$ grade $\mathrm{B}_{4} \mathrm{C}$ has $97.9 \%$ relative density.

TABLE I

Density values of differently processed HP and HS grade sintered boron carbide ceramics.

\begin{tabular}{|c|c|c|c|c|}
\hline & $\begin{array}{l}\text { Starting } \\
\text { powder }\end{array}$ & Dimensions & $\begin{array}{c}\text { SPS process } \\
{\left[{ }^{\circ} \mathrm{C}, \mathrm{MPa}, \mathrm{min}\right]}\end{array}$ & $\begin{array}{c}\text { Relative } \\
\text { density [\%] }\end{array}$ \\
\hline 1. & $\begin{array}{l}\mathrm{B}_{4} \text { Cpowder } \\
\text { (HP grade) }\end{array}$ & $\begin{array}{c}(\varnothing 50 \mathrm{~mm}, \\
5 \mathrm{~mm} \text { thickness })\end{array}$ & $1800,50,5$ & 97.9 \\
\hline 2. & $\begin{array}{c}\mathrm{B}_{4} \mathrm{C} \text { powder } \\
\text { (HS grade) }\end{array}$ & $\begin{array}{c}(\varnothing 50 \mathrm{~mm}, \\
5 \mathrm{~mm} \text { thickness })\end{array}$ & $1770,50,5$ & 99.4 \\
\hline 3. & $\begin{array}{c}\mathrm{B}_{4} \mathrm{C} \text { powder } \\
\text { (HP grade) }\end{array}$ & $\begin{array}{c}(\varnothing 50 \mathrm{~mm}, \\
8 \mathrm{~mm} \text { thickness })\end{array}$ & $1700,40,5$ & 98.6 \\
\hline 4. & $\begin{array}{l}\mathrm{B}_{4} \mathrm{C} \text { powder } \\
\text { (HS grade) }\end{array}$ & $\begin{array}{c}(\varnothing 50 \mathrm{~mm}, \\
8 \mathrm{~mm} \text { thickness })\end{array}$ & $1670,40,5$ & 99.1 \\
\hline 5. & $\begin{array}{l}\mathrm{B}_{4} \mathrm{C} \text { powder } \\
\text { (HP grade) }\end{array}$ & $\begin{array}{l}(50 \mathrm{~mm} \times 50 \mathrm{~mm} \\
\text { square cross-section, } \\
8 \mathrm{~mm} \text { thickness })\end{array}$ & $1550,40,5$ & 98.7 \\
\hline 6. & $\begin{array}{c}\mathrm{B}_{4} \mathrm{C} \text { powder } \\
\text { (HS grade) }\end{array}$ & $\begin{array}{c}(50 \mathrm{~mm} \times 50 \mathrm{~mm} \\
\text { square cross-section, } \\
8 \mathrm{~mm} \text { thickness })\end{array}$ & $1530,40,5$ & 98.9 \\
\hline 7. & $\begin{array}{l}\mathrm{B}_{4} \mathrm{C} \text { powder } \\
\text { ( } \mathrm{HS} \text { grade) } \\
+5 \% \mathrm{Y}_{2} \mathrm{O}_{3}\end{array}$ & $\begin{array}{c}(\varnothing 50 \mathrm{~mm}, \\
5 \mathrm{~mm} \text { thickness })\end{array}$ & $1740,40,5$ & 99.5 \\
\hline
\end{tabular}

TABLE II

Hardness and fracture toughness values of HP and HS grade sintered boron carbide ceramics.

\begin{tabular}{|c|c|c|c|c|}
\hline & $\begin{array}{l}\text { Starting } \\
\text { powder }\end{array}$ & $\begin{array}{c}\text { SPS process } \\
{\left[{ }^{\circ} \mathrm{C}, \mathrm{MPa}, \mathrm{min}\right]}\end{array}$ & $\begin{array}{l}\text { Hardness } \\
\text { [GPa] }\end{array}$ & $\begin{array}{c}\text { Fracture } \\
\text { toughness } \\
{\left[\mathrm{MPa} \mathrm{m} \mathrm{m}^{1 / 2}\right]}\end{array}$ \\
\hline 1. & $\begin{array}{c}\mathrm{B}_{4} \mathrm{C} \text { powder } \\
\text { (HP grade) }\end{array}$ & $1800,50,5$ & $32.6 \pm 0.5$ & $4.30 \pm 0.70$ \\
\hline 2 . & $\begin{array}{c}\mathrm{B}_{4} \mathrm{C} \text { powder } \\
\text { (HS grade) }\end{array}$ & $1770,50,5$ & $32.2 \pm 0.5$ & $4.30 \pm 0.70$ \\
\hline 3. & $\begin{array}{c}\mathrm{B}_{4} \mathrm{C} \text { powder } \\
\text { (HP grade) }\end{array}$ & $1700,40,5$ & $31.04 \pm 0.5$ & $4.21 \pm 0.70$ \\
\hline 4. & $\begin{array}{l}\mathrm{B}_{4} \mathrm{C} \text { powder } \\
\text { (HS grade) }\end{array}$ & $1670,40,5$ & $30.67 \pm 0.5$ & $4.20 \pm 0.70$ \\
\hline 5. & $\begin{array}{l}\mathrm{B}_{4} \mathrm{C} \text { powder } \\
\text { ( } \mathrm{HP} \text { grade) }\end{array}$ & $1550,40,5$ & $32.9 \pm 0.5$ & $2.69 \pm 0.30$ \\
\hline 6. & $\begin{array}{l}\mathrm{B}_{4} \mathrm{C} \text { powder } \\
\text { (HS grade) }\end{array}$ & $1530,40,5$ & $33.5 \pm 0.5$ & $2.55 \pm 0.30$ \\
\hline 7. & $\begin{array}{c}\mathrm{B}_{4} \mathrm{C} \text { powder } \\
(\mathrm{HS} \text { grade) } \\
+5 \% \mathrm{Y}_{2} \mathrm{O}_{3}\end{array}$ & $1740,40,5$ & $36.7 \pm 0.5$ & $3.70 \pm 0.30$ \\
\hline
\end{tabular}

The third and fourth samples stated in Table I have $50 \mathrm{~mm}$ diameter and $8 \mathrm{~mm}$ thickness. Shrinkage of the $\mathrm{HP}$ and HS graded cylindrical samples having $50 \mathrm{~mm}$ diameter and $8 \mathrm{~mm}$ thickness are completed at $1700^{\circ} \mathrm{C}$ and $1670{ }^{\circ} \mathrm{C}$, respectively. $40 \mathrm{MPa}$ pressure is applied under vacuum atmosphere and the powders are heated with $75^{\circ} \mathrm{C} / \mathrm{min}$ heating rate with $5 \mathrm{~min}$ soaking time. The third sample (HP grade) has $98.6 \%$ relative density whereas the fourth sample (HS grade) has $99.1 \%$ relative density.

The fifth and sixth samples stated in Table I have $50 \times 50 \mathrm{~mm}^{2}$ square cross-sectional area. Shrinkage of the HP and HS graded square samples are completed at $1550{ }^{\circ} \mathrm{C}$ and $1530^{\circ} \mathrm{C}$, respectively. $40 \mathrm{MPa}$ pressure is applied under vacuum atmosphere and the powders are heated with $75^{\circ} \mathrm{C} / \mathrm{min}$ heating rate and sintered for 5 min. The fifth sample (HP grade) has $98.7 \%$ relative density whereas the sixth sample (HS grade) has $98.9 \%$ relative density. The seventh sample which has $5 \% \mathrm{Y}_{2} \mathrm{O}_{3}$ has $99.5 \%$ relative density. The thicker the sample gets, the lower the sintering temperature gets due to the heat created from the excess powder in thicker samples.

The hardness and fracture toughness values of the sintered ceramics are given in Table II. Hardness values of the $\mathrm{HP}$ grade $\mathrm{B}_{4} \mathrm{C}$ ceramics sintered at $1800^{\circ} \mathrm{C}$ are obtained as $32.6 \pm 0.5 \mathrm{GPa}$; $\mathrm{HS}$ grade $\mathrm{B}_{4} \mathrm{C}$ ceramics sintered at $1770{ }^{\circ} \mathrm{C}$ are obtained as $32.2 \pm 0.5 \mathrm{GPa}$. Addition of $5 \%$ mass $\mathrm{Y}_{2} \mathrm{O}_{3}$ to $\mathrm{HS}$ grade $\mathrm{B}_{4} \mathrm{C}$ resulted in an increase in hardness values from $32.2 \pm 0.5$ to $36.7 \pm 0.5$. The highest fracture toughness values are obtained as $4.3 \pm 0.7 \mathrm{MPa} \mathrm{m}{ }^{1 / 2}$ from the samples with smaller dimensions (Ø50 mm, $5 \mathrm{~mm}$ thickness) heated with $100^{\circ} \mathrm{C} / \mathrm{min}$ heating rate and spark plasma sintered at $1800^{\circ} \mathrm{C}$ for $5 \mathrm{~min}$.

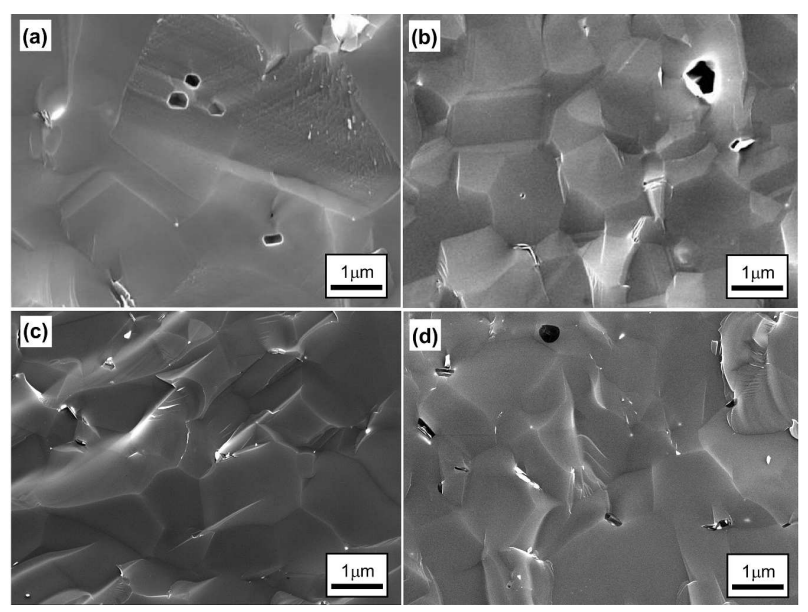

Fig. 1. SEM micrographs of (a) HP grade sintered $\mathrm{B}_{4} \mathrm{C}$ at $1800{ }^{\circ} \mathrm{C}$ and (b) $\mathrm{HS}$ grade sintered $\mathrm{B}_{4} \mathrm{C}$ at $1770{ }^{\circ} \mathrm{C}$ with $100{ }^{\circ} \mathrm{C} / \mathrm{min}$ heating rate and $5 \mathrm{~min}$ soaking time, applied pressure of $50 \mathrm{MPa}$, (c) $\mathrm{HS}$ grade $\mathrm{B}_{4} \mathrm{C}$ (Ø50 mm, $8 \mathrm{~mm}$ thickness) sintered at $1670^{\circ} \mathrm{C}$ under $40 \mathrm{MPa}$ pressure for $5 \mathrm{~min}$, (d) $\mathrm{HS}$ grade $\mathrm{B}_{4} \mathrm{C}(50 \mathrm{~mm} \times$ $50 \mathrm{~mm}$ square cross-section, $8 \mathrm{~mm}$ thickness) sintered at $1530{ }^{\circ} \mathrm{C}$ under $40 \mathrm{MPa}$ pressure for $5 \mathrm{~min}$.

Fracture surface SEM images are given in Fig. 1, which provided the best result of relative density values. HS grade $\mathrm{B}_{4} \mathrm{C}$ is observed to have $1-2 \mu \mathrm{m}$ average grain size 


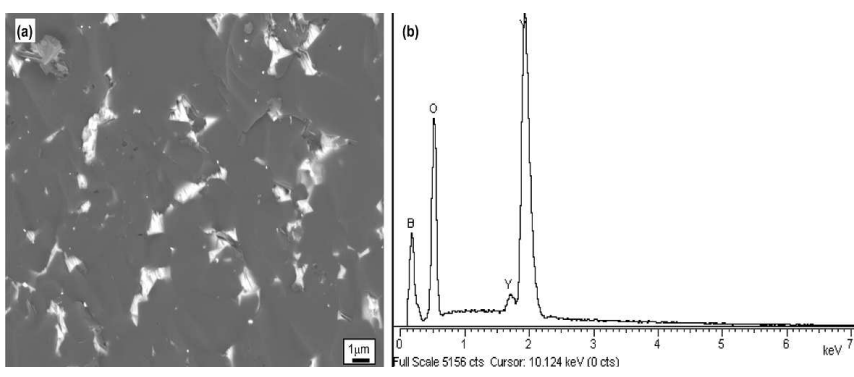

Fig. 2. (a) SEM micrographs of HS grade sintered $\mathrm{B}_{4} \mathrm{C}$ with $5 \% \quad \mathrm{Y}_{2} \mathrm{O}_{3}$ additive sintered at $1740{ }^{\circ} \mathrm{C}$ with $100{ }^{\circ} \mathrm{C} / \mathrm{s}$ heating rate and $5 \mathrm{~min}$ soaking time, applied pressure of $50 \mathrm{MPa}$ and under vacuum atmosphere, (b) EDS analysis of the white sections in HS grade $\mathrm{B}_{4} \mathrm{C}$ sample with $5 \% \mathrm{Y}_{2} \mathrm{O}_{3}$ additive.

whereas $\mathrm{HP}$ grade $\mathrm{B}_{4} \mathrm{C}$ is observed to have $2-3 \mu \mathrm{m}$ average grain size. Difference of the grain sizes of sintered HS and HP grade ceramics are due to the starting powder grain size difference. The sintered ceramics are observed to have pores which are not equal in size and distribution from each other.

SEM micrographs of $\mathrm{Y}_{2} \mathrm{O}_{3}$ added $\mathrm{B}_{4} \mathrm{C}$ samples which exhibits equal or higher relative density values are given in Fig. 2. Pore level is detected to be less than $1 \%$ and the white sections are assumed to be $\mathrm{YB}_{12}$ and $\mathrm{Y}_{4} \mathrm{C}_{7}$ phases. As provided in Fig. 2 in the EDS analysis white parts contain Y, O, and B elements. XRD analysis shows that $\mathrm{YB}_{12}$ is present in the structure. EDS analysis shows the presence of oxygen which leads to the assumptions of $\mathrm{B}_{2} \mathrm{O}_{3}$ presence.

\section{Conclusions}

In this study, highly densified boron carbide ceramics processed under argon atmosphere with density values higher than $97 \%$ was attained by SPS technique at various temperatures: $1770{ }^{\circ} \mathrm{C}, 1670^{\circ} \mathrm{C}, 1530^{\circ} \mathrm{C}$ and $1740^{\circ} \mathrm{C}$ for $\mathrm{HS}$ graded $\mathrm{B}_{4} \mathrm{C}$ powders. $\mathrm{HP}$ graded powders with $100{ }^{\circ} \mathrm{C} / \mathrm{min}$ heating rate under $50 \mathrm{MPa}$ applied pressure and 5 min soaking times. The Vickers hardness of the samples ranged between $30.67 \pm 0.5$ and $36.7 \pm 0.5 \mathrm{GPa}$ and fracture toughness values were measured between
$2.55 \pm 0.3$ and $4.3 \pm 0.3 \mathrm{MPa} \mathrm{m}{ }^{1 / 2}$. Hayun et al. measured the fracture toughness values from the Palmqvist crack system equations to be between 3.9 and $4.9 \mathrm{MPa} \mathrm{m}^{1 / 2}[6]$. In addition, the pure HS and HP graded ceramics which had the highest fracture toughness values were achieved from the process where higher heating regime and higher pressure was applied. Moreover, the sample with smallest dimensions and volume led to the highest sintering temperature and fracture toughness.

When cylindrical geometry is used in SPS, it is possible to relate the measured temperature to the temperature measured by the value from the optical pyrometer using a simple model. If the sample is assumed to be small, thin and centrally positioned, the temperature distribution will be according to the graphite die. The temperature difference between the edge of the die and the centre of the sample is therefore strongly dependent on the die surface temperature, the properties and geometry of the die and the sample. Very minor changes in the die geometries, dimensions and die wall thickness affect the SPS process parameters drastically [7].

\section{Acknowledgments}

The authors express their gratitude to Istanbul Technical University Department of Scientific Research Projects-BAP for their financial support.

\section{References}

[1] F. Thévenot, J. Europ. Ceram. Soc. 6, 205 (1990).

[2] H. Lee, R.F. Speyer, J. Am. Ceram. Soc. 86, 1468 (2003).

[3] M. Omori, Mat. Sci. Eng. A 287, 183 (2000).

[4] H.O. Pierson, Handbook of Refractory Carbides and Nitrides Properties, Characteristics, Processing and Applications, Consultant and Sandia National Laboratories, New Mexico 1996.

[5] S. Hayun, S. Kalabukhov, V. Ezersky, M.P. Dariel, N. Frage, Ceram. Int. 36, 451 (2009).

[6] S. Hayun, V. Paris, M.P. Dariel, N. Frage, E. Zaretzky, J. Europ. Ceram. Soc. 29, 3395 (2009).

[7] R.S. Dobedoe, G.D. West, M.H. Lewis, Adv. Appl. Ceram. 104, 110 (2005). 